\title{
PREPARING TO TEACH MUSIC IN THE PRIMARY SCHOOL
}

\author{
Benjamin Adjepong (Corresponding Author) \\ Wesley College of Education, \\ Kumasi, Ghana. \\ ben.adjepong@yahoo.com \\ John Kofi Brewu (Rev) \\ Akrokerri College of Education, \\ Akrokerri, Ghana.
}

\begin{abstract}
Teaching is the primary duty of teachers. For effective teaching and learning of music in the primary school to take place, teachers are supposed to consider pre-teaching preparation. Some activities that should be considered and included in the preparation stage include the study of content of the syllabus, preparation of the lesson plan, and gathering and preparation of teaching and learning aids/materials. This paper considers pre-teaching preparation for effective teaching of music in the primary school.
\end{abstract}

KEYWORDS: teaching, music, primary school, lesson preparation, lesson planning

\section{INTRODUCTION}

In this paper, an attempt is made to present an overview of how best to consider pre-teaching preparation for effective teaching of music in the primary school. In this 21 st century world, every society ensures the transmission and perpetuation of its culture, norms and values through established educational institutions such as the primary school. According to Flolu and Amuah (2003, p. 92), "schools are artificial institutions designed by society to explore, analyse and criticise our culture in a special way." The school's duty is, therefore, to ensure the acquisition of these cultural values and norms by citizens through the implementation of the national curriculum (Boamajeh \& Ohene-Okanta, 2000). According to Ramsden (2003), the curriculum is the way through which society tries to meet its educational goals. In effect, knowledge, norms, skills, values and understanding are gained through interplay between teaching and learning.

Teachers perform a variety of duties at their work place. However, the core duty of the teacher is the practice of teaching while the other duties performed "might be considered ancillary" (Tawiah et al. 2016, p. 17), serving to facilitate pupils' learning. The term 'Teaching' has been explained and defined in various ways. Koomson et al. (2003) describe teaching as an art in terms of "the different skills and tools, verbal and non-verbal communicative skills and materials which the teacher presents the learning activities in a meaningful way to the pupils" (p. 22). Ball and Forzani (2009) refer to teaching as the duties teachers must perform to assist pupils to learn. Citing Schlechty (2004), Ababio (2013) state that "teaching as an art of inducing students to behave in ways that are assumed to lead to learning" (38). Ababio (ibid) explained further that "what Schlechty meant by teaching being 'an art' is that the teacher must create situations to facilitate learning and then motivate learners to have interest in what is being 
Vol.8, Issue 4, pp.70-81, April 2020

Published by ECRTD- UK

Print ISSN: ISSN 2054-6351

Online ISSN: ISSN 2054-636X

transmitted to them." With these claims in mind, it could be argued that the main purpose of teaching music is to create the necessary environment to facilitate pupils' learning for acquisition of knowledge, skills and understanding in the art. This makes the teacher's role in the teaching and learning process very crucial.

Effective music teachers must possess understanding, skills and knowledge that will enable them to know when, who, how and what to teach in the music classroom. Using phenomenological research design to investigate the qualities of effective teachers, Misigo, Kodero and Too (2014) captured the following themes which emerged from ninety student respondents' perceptions of effective teachers, which include:

- Good sense of humour

- Mastery in content (subject-matter)

- Caring and understanding to pupils

-Explains concepts to the understanding of all pupils

- Patient and respectful to all pupils

- Is God fearing

- Focused and self-control

- Well composed

- Presentable and smart

- Regular and punctual to class

- Correct pupils' errors politely

- Assist pupils to work hard

- Pronounces word clearly

- Fair to all pupils

- Marks pupils' exercises promptly

- Provide counselling services to pupils

- Help academically weak pupils

- Friendly to all pupils

- Prepares well and adequately for teaching

- Engage all pupils in lessons

- Encourage questioning in class

- Honest and admit errors

- Committed to duty

- Organised.

Possessing and application of the above outlined characteristics in the primary school classroom can enable the teacher to deliver music content effectively in a comprehensive manner to primary school pupils (Boafo-Agyemang, 2010) and, thereby, result in effective teaching.

\section{Effective Teaching}

Effective teaching of music can leads to pupils' attainment of appreciation of music and development in musical skills and knowledge (Button, 2010). Harris, Mishra and Koehler (2009) are of the view that effective teaching can be accomplished if the classroom teacher can relate curriculum content and methods of teaching with the use of appropriate media, supported by the environment to provide the individual educational needs of his or her pupils. According 
to Wenglinsky (2000), effective teaching is premised on teachers who frequently involve the entire class in discussions, provide rewards, talk to pupils about their work output, engage pupils with variety of work, and try to make their lessons very stimulating. Effective teaching provide pupils with opportunities to respond to their teacher and peers' presentations, motivates them to learn, and establishes a positive bond of relationship between teacher and learner (Tamakloe, Atta \& Amedahe, 2005).

Writing in 1988, Farrant acknowledged that the teacher can ensure effective teaching through an excellent knowledge of how pupils learn, how to choose the appropriate teaching and learning materials, use of teaching methods appropriate to pupils' age and abilities, how to communicate responses to pupils' questions, managing children's behaviour and also how to plan effective lessons. Philip Gurney is also of the view that the interaction of five key factors constitutes the foundation for an effective and good teaching, and these are:

- "Teacher knowledge, enthusiasm and responsibility for learning

- Classroom activities that encourage learning

- Assessment activities that encourage learning through experience

- Effective feedback that establishes the learning processes in the classroom

- Effective interaction between the teacher and the pupils, creating an environment that respects, encourages and stimulates learning through experience" (Gurney 2007, p. 91).

Cohen, Manion, Morrison and Wyse (2010, p. 189) have outlined the following ten principles of effective teaching derived from educational research. These writers claim that 'effective pedagogy':

- "equips learners for life in its broadest sense

- engages with valued forms of knowledge

- recognises the importance of prior experience and learning

- requires learning to be scaffolded

- needs assessment to be congruent with learning

- promotes the engagement of the learner

- fosters both individual and social processes and outcomes

- recognises the significance of informal learning

- depends on the learning of all those who support the learning of others

- demands consistent policy frameworks with support for learning as their primary focus."

For effective teaching to happen in the primary school music classroom, it is very significant for teachers to plan their teaching activities with these characteristics and principles in mind in order to provide meaningful musical experiences to their pupils. 
Vol.8, Issue 4, pp.70-81, April 2020

Published by ECRTD- UK

Print ISSN: ISSN 2054-6351

Online ISSN: ISSN 2054-636X

\section{LESSON PLANNING AND PREPARATION}

A fundamental principle of effective teaching of music is lesson preparation in which the teacher undertakes advance planning to ensure smooth implementation of envisaged teaching and learning activities. Indeed, planning in advance encourages the teacher to feel confident and secure, which, in effect, helps him or her to be effective in the classroom (Boamajeh \& Ohene-Okanta, 2000).

Activities that cover the lesson preparation stage may include the interpretation of the curriculum content through the study of the subject syllabus, pupil's course books and teacher's teaching manuals (Farrant, 1988). It also covers preparation of scheme of work based on the content of the syllabus, preparation of the lesson plan from the scheme of work, and selection and preparation of teaching and learning aids or materials based on the lesson activities and objectives planned by the teacher (Baiden \& Amofa, 2008). In the following paragraphs, we have attempted to present overview of the various curriculum materials used for lesson preparation.

\section{The Syllabus/Curriculum Content}

The syllabus consists of the interpretation of the curriculum content (Baiden \& Amofa, 2008). According to Tamakloe et al. (2005), it provides a description of what content or subject matter needs to be taught in the various disciplines. The syllabus presents the way in which societies intend to achieve their educational goals such as accepted standards of behaviour, values, norms and practices expected of each citizen, and preparing human resources for the world of work (Adjei-Mensah et al., 2001; Boamajeh \& Ohene-Okanta, 2000). Thus, the syllabus gives the teacher a focus and right direction to follow in his or her work in the classroom. The syllabus outlines the general objectives for each topic to be taught and learned, suggests teaching and learning activities, and prescribes the procedure for assessing students' learning based on their experiences (Adjei-Mensah et al., 2001; Baiden \& Amofa, 2008).

\section{Text Book/Teaching Manual}

The pupil's text books contain the materials that assist in achieving the general objectives outlined in the syllabus, while the teacher's manual provides guidelines on how the teacher should plan teaching and learning activities for implementation in the classroom (Baiden \& Amofa, 2008). A comprehensive study of the various curriculum materials should, therefore, be a prime concern to the teacher, as this practice results in providing a direction to follow in the teaching and learning process.

\section{The Scheme of Work}

The scheme of work is a document prepared by the teacher that contains the interpretation of the syllabus (Tamakloe et al., 2005). It comprises the topics in the syllabus broken down into a series of lessons and indicates the teaching methods to be employed, aim of the scheme, sources of information, the duration for teaching a particular topic, teaching aids or materials to be used for teaching a particular topic, the previous knowledge and experience of students, assessment procedures of student's learning, and particulars of pupils for which the scheme is intended (Adjei-Mensah et al., 2001; Cohen et al., 2010; Tamakloe et al., 2005). The scheme of work also gives an idea of the volume of work pupils must cover within a given time frame. 
British Journal of Education

Vol.8, Issue 4, pp.70-81, April 2020

Published by ECRTD- UK

Print ISSN: ISSN 2054-6351

Online ISSN: ISSN 2054-636X

Thus, it is a curriculum document prepared in advance by the teacher to serve as a reference material to guide and direct teaching. It can, therefore, be considered as a useful tool for ensuring continuity and consistency in the teaching and learning of music and ensures that the teacher bases his or her teaching on the approved national curriculum.

\section{The Lesson Plan}

An important indication of a teacher's preparedness is a well prepared and written lesson plan. The lesson plan is a programme of the activities a teacher follows in teaching a given lesson. It outlines the steps that the teacher will follow to present a lesson on a specific topic and is intended to guide him or her to proceed logically and sequentially in his or her delivery (Baiden \& Amofa, 2008; Tamakloe et al., 2005). The lesson plan indicates the specific objectives to be achieved by the end of the lesson, the relevant previous knowledge of learners, the teacher and learner activities, the teaching and learning materials (teaching aids) to be used, the core points to be covered and evaluation exercises or expression work (Baiden \& Amofa, 2008). The lesson plan is essential since it enables the teacher to evaluate his or her teaching and make improvements, and also encourages him or her to prepare adequately before teaching (Baiden \& Amofa, 2008).

Although some music educators have written and published articles on lesson plan preparation (Branscome, 2014; Wacker, 2016), I have attempted to present brief overview of the content of the lesson plan in the following paragraphs.

\section{The Specific Objectives}

According to Adjei-Mensah et al. (2001), specific objectives are statements which outline the knowledge, skills, understanding and attitudes learners are expected to acquire by the end of the lesson. Objectives are stated in measurable student behaviour outcome (Tamakloe et al., 2005), that is, the change in pupil's behaviour as a result of teaching. Adjei-Mensah et al. (2001, p. 22) outline the following features of good lesson objectives, claiming that they:

- "must state clearly the behavioural change you expect in your pupils

- must be achievable within a specified time

- change in the pupils' behaviour must be that which you can observe and measure."

To this end, it is important to use performance verbs such as 'sing,' 'move,' 'create,' 'play' 'dance' and so on in order to make lessons more focused. An example of a behavioural objective as stated in the lesson plan is: 'By the end of the lesson, the pupil will be able to clap rhythmic patterns to accompany a song.' This statement demonstrates that the pupils' performance can be measured since he or she has performed a specific task. In this sense, a behavioural objective should be measurable, specific, observable, and achievable (AdjeiMensah et al., 2001; Baiden \& Amofa, 2008)

According to Tamakloe et al. (2005) behavioural objectives are based on cognitive, affective and psychomotor domains. The cognitive domain deals with mental activities and skills of knowledge, understanding, application, analysis, synthesis, and evaluation (National Council 
Vol.8, Issue 4, pp.70-81, April 2020

Published by ECRTD- UK

Print ISSN: ISSN 2054-6351

Online ISSN: ISSN 2054-636X

for Curriculum and Assessment of Ghana [NaCCA], 2019; Owusu-Banahene, 2008; Tamakloe et al., 2005). According Owusu-Banahene (2008) the affective domain concerns personal emotions which influence his or her interests, attitude, values and appreciation. Teaching activities that usually employ practical activities involving demonstration of manipulative skills generally refer to the psychomotor domain (NaCCA, 2019) Therefore, it is important for teachers to recognise the need to set objectives that encompass cognitive, affective and psychomotor domains to develop pupils' understanding, knowledge, attitude and skills in musical learning. Adjei-Mensah et al. (2001) are of the view that having more than one objective in a lesson provides an opportunity for the teacher to look for other outcomes in or across different domains.

\section{The Relevant Previous Knowledge}

The relevant previous knowledge (RPK) is a statement of knowledge, skills and ideas which learners have acquired through daily experiences (Tamakloe et al., 2005). They may either be what students have learned in a previous lesson or experiences they have acquired outside the school environment. Adjei-Mensah et al. (2001) have noted that the relevant previous knowledge is the basis upon which teachers build new lessons. In this sense, it helps the teacher to know the level at which to begin a lesson and to link the new topic to the pupils' background experience. Knowledge of pupils' RPK guides the teacher to teach from concrete to abstract, known to unknown, and simple to complex (Flolu \& Amuah, 2003).

\section{Teacher and Learner Activities}

Adjei-Mensah et al. (2001) opine that teacher and learner activities are statements of how teachers plan to organise teaching and learning to achieve the stated objectives in the lesson plan. It includes the various teaching methods and techniques the teacher deploys, application of teaching and learning aids, and all the interactional networks, that is, pupils' responses to their peers or the teacher's demonstrations and actions that go on during the teaching and learning process (Baiden \& Amofa, 2008). Thus, this provides an idea of all the learning experiences the teacher may provide to learners during the teaching and learning process in the music classroom. Classroom music experiences are built upon the pupil's past experiences and aligned with the stated objectives of the lesson (Flolu \& Amuah, 2003).

\section{Teaching and Learning Aids/Materials}

Pupils in the primary school (ages 6 to 12) are in a mental stage which Jean Piaget named Concrete-Operational stage (Barbara \& Pope, 2008; Sematwa, 2010). These writers emphasise children's construction of their own knowledge and understanding derived from concrete experiences through interaction with the environment. Tawiah et al. (2016) also state that "appropriate equipment/resources could be used to further develop skills and knowledge" (p. 19). These suggest the significance of providing appropriate musical instruments for pupils to engage in experimentation and to explore music on their own. In this regard, pupils learn and understand concepts better through the use of concrete materials which are very crucial in teaching music.

Teaching and learning aids are materials that a teacher uses to facilitate and augment his or her teaching (Tamakloe et al., 2005). Đurđanović (2015) defines them as "didactically shaped 
Vol.8, Issue 4, pp.70-81, April 2020

Published by ECRTD- UK

Print ISSN: ISSN 2054-6351

Online ISSN: ISSN 2054-636X

objects, products of human work, which are used in the teaching process as sources of cognition/learning" (p. 33). Reece and Walker wrote in 1994 and argued that psychologists assign $12 \%$ of what children learn through hearing and $75 \%$ through what they see. The Irish National Teachers' Organisation (INTO, 2007) confirms this by stating that $75 \%$ of pupils' learning is retained through experimentation. In other words, pupils' are able to retain what they learn better by using concrete objects during teaching and learning process. This has an implication for the use of teaching and learning aids in teaching music to pupils.

The study of music in the primary school is underpinned by practical activities through the use of concrete teaching and learning aids (Isbell \& Raines, 2003). Pupils also make use of parts of their bodies to create rhythmic sounds through clapping, tapping of thighs, rubbing hands together, and snapping of fingers (Essa, 2003; Isbell \& Raines, 2003), activities that aid music learning. There are also various classroom audio-visual materials such as the television, radio, computer, projector, video compact disc (VCD), digital versatile disc (DVD) and other related materials (Adjei-Mensah et al., 2001) that can be used to teach music. According to NacinoBrown et al. (1982), students remember fifty per cent (50\%) of what they hear and see as compared to ten per cent (10\%) of what they read, and twenty per cent $(20 \%)$ of what they hear. These suggest that a combination of teaching materials that cater for both sound and visual perception results in effective teaching and learning (Tamakloe et al., 2005).

There are other varieties of teaching aids in the form of musical instruments in various shapes, sizes, classes and types that can be used to teach music effectively in the primary school. Hickok (1993) classified such musical instruments into voices (such as soprano, mezzosoprano, tenor and bass), strings (such as violin, viola, violoncello and double bass), woodwind (such as flute, clarinet, piccolo, oboe and bassoon), brasses (such as trumpet, trombone, horn and tuba), percussion (such as timpani, glockenspiel, celesta and chimes), and keyboards (such as organ, piano and harpsichord).

Generally, African musical instruments are generally categorised as membranophones, idiophones, aerophones and chordophones, according to their mode of sound production (Agordoh, 1994; Amuah, Adum-Attah \& Arthur, 2011; Amuah \& Adum-Attah, 2016; Nketia, 1988). Membranophones are drums with parchment heads whose sound is produced by striking with a stick or hand. The names of some examples of these instruments in the Akan language of Ghana are donno, atumpan, petia, kwadum and etwie (Amuah, et al., 2011). According to Nketia (1988), an idiophone may be "defined as any instrument upon which a sound may be produced without the addition of a stretched membrane or a vibrating string or reed" (p. 69). Idiophones are made of naturally sonorous materials and, therefore, do not need additional tension to produce sounds (Amuah et al., 2011). Examples in the Akan language are frikyiwa, dawuro, trowa, adenkum and dansuom. Chordophones are string instruments that produce sound by causing strings to vibrate (Amuah et al., 2011). Examples in Akan are seprewa and benta. Aerophones are wind instruments and sound is obtained by blowing air through them (Amuah et al., 2011). Examples in Akan are atcnteben, atcntebenba, odurogya, odurogyaba and mmensuon. 


\section{PICTURES OF SOME AFRICAN TRADITIONAL MUSICAL INSTRUMENTS}

\section{Membranophones}

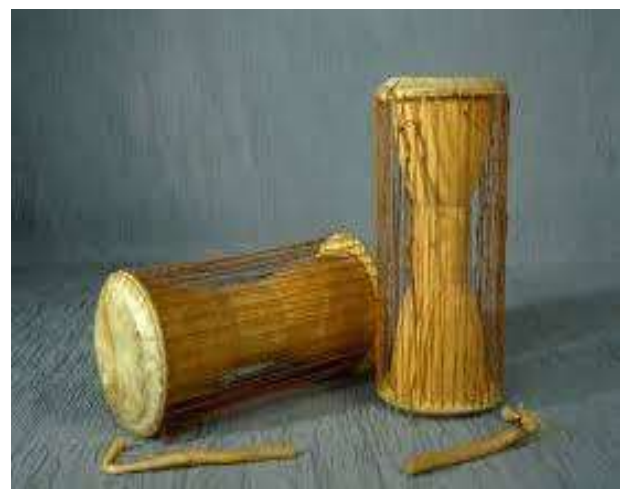

Donno

\section{IDIOPHONES}

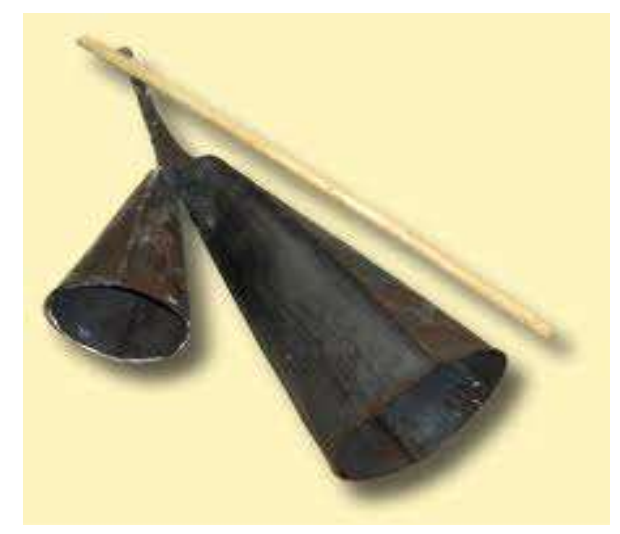

Dawuro

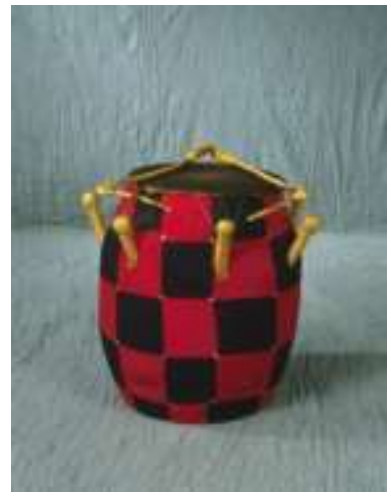

Kwadum

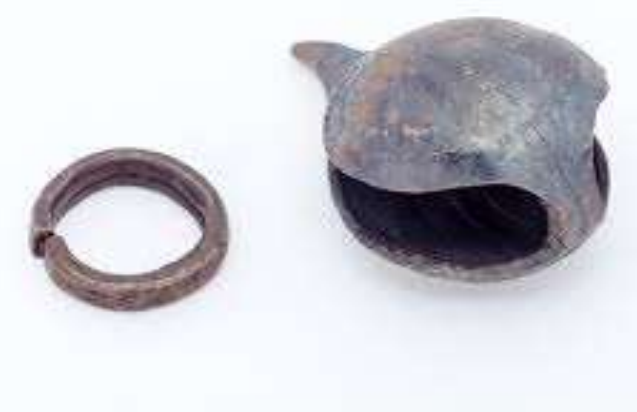

Frikyiwa

AEROPHONE

Atenteben

CHORDOPHONE 


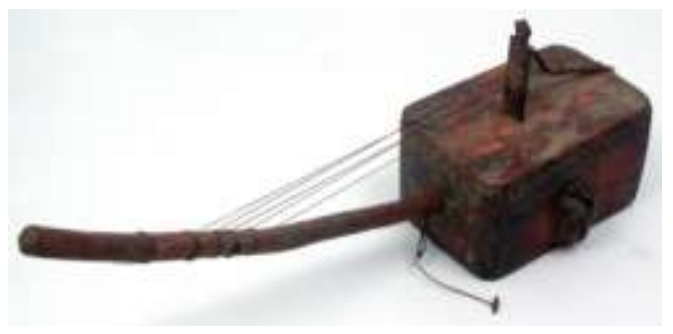

Seprewa

Flolu and Amuah (2003) have identified how pupils develop and create their own musical instruments using materials such as empty tins and cans, polythene sheets, sticks and hollow objects which are readily available in the environment, and have encouraged teachers to support such initiatives to develop pupil's creative skills and also obtain improvised materials for teaching. This is necessary in Ghana due to challenges associated with accessibility of real musical instruments for instructional purposes. In their research, Boafo-Agyemang (2010) and Ampeh (2011) identified that lack of teaching aids is affecting the teaching of Creative Arts in Ghanaian primary schools and recommended that the Ghana Education Service collaborate with parents and teachers to see to the end of this challenge.

Outlining the importance of teaching aids, Ekpo and Igiri (2015, p. 27-28) cited Brown et al. (2005) and state that teaching aids:

- promote meaningful communication and effective learning

- ensure better retention, thus making learning more permanent

- help to overcome the limited classroom by making the inaccessible accessible

- provide a common experience upon which late learning can be develop

- stimulate and motivate pupils to learn

- encourage participation especially if pupils are allowed to manipulate materials used.

The outlined role of the use of teaching aid, and their impact on pupils' musical learning experiences require teachers to select appropriate and suitable ones for teaching.

\section{The Core Points}

The core points are the stated main ideas, knowledge, skills, concepts and attitudes the teacher wants to develop in learners at each stage of the lesson (Adjei-Mensah et al., 2001; Baiden \& Amofa, 2008). According to Alorvor (2012), the core points "refer to the individual concepts dealt with in the lesson" (p. 6). They are stated as briefly as possible in the lesson plan and are based on the topic to be taught and the set objectives of the lesson. In effect, the core points are not specific points on how the lesson is taught but rather used to guide the activities of the teacher and the learners. 
Vol.8, Issue 4, pp.70-81, April 2020

Published by ECRTD- UK

Print ISSN: ISSN 2054-6351

Online ISSN: ISSN 2054-636X

\section{Evaluation Exercises and Expression Work}

Evaluation exercises and expression work are recorded activities that pupils will engage in during and after the lesson presentation to enable the teacher to assess each pupil's level of mastery and understanding of the lesson taught (Adjei-Mensah et al., 2001). According to Baiden and Amofa (2008), pupils' responses to the evaluation exercises provide an indication of the level of achievement of the stated objectives and what remedial work needs to be organised for learners. Learners who receive constant feedback on evaluation of their musical learning become aware of their progress and this motivates them to develop the habit of engaging in self-evaluation of their learning (McPherson \& Renwick, 2011). By extension, the teacher's evaluation of his or her students' learning in music helps him or her to adjust his or her teaching to align with the interests, experiences and needs of pupils.

\section{Lesson Evaluation}

Another area of importance with regard to effective music teaching is the teacher's selfevaluation of the lesson he or she has taught. This is achieved through a reflection-on-action. Robinson and Kochan (2000) have stated that "reflection-on-action is based on the individual reviewing a prior experience, analysing what caused the interactions or reactions, and determining what might be done differently in future" (p. 64). These writers are of the view that these actions provide means for the teacher to critically engage in self-assessment to consider more effective alternatives which eventually leads to improvement in teaching. AdjeiMensah et al. (2001, p. 29) outlined the following questions the teacher can ask himself or herself in the process of evaluating the lesson he or she has taught:

- Did I review the previous knowledge of my pupils?

- Did I link the previous knowledge to the new topic?

- Did I involve all the pupils in the lesson?

- Did I present my materials sequentially?

- Did I make effective use of teaching-learning materials?

- Did I help the pupils to understand the materials I presented?

\section{CONCLUSION}

Finding answers to the above stated questions is likely to lead to effective evaluation of one's teaching activities to improve professional practice. Indeed, this makes the teacher a reflective practitioner where he or she always examines his or her teaching critically for the purpose of improving upon his or her practices in the classroom (Jay \& Johnson, 2002).

\section{REFERENCE}

Ababio, B. T. (2013). Nature of teaching: What teachers need to know and do. International Journal for Innovative Education and Research 1(3), 37-48.

Adjei-Mensah, I. et al., (2001). Teaching education studies for basic school teachers. Accra, Ghan: Ghana Education Service.

Agordoh, A. A. (1994). Studies in African music. Ho, Ghana: Age Publication.

Alorvor, L. K. (2012). Effective teaching strategies for teachers (3rd Ed). Accra, Ghana: Spirit, Soul and Body. 
Ampeh, G. K. (2011). Developing effective strategies for teaching creative arts in the lower primary school: A case in Agona Swedru district administration 'B' school. Kumasi, Ghana: Kwame Nkrumah University of Science and Technology.

Amuah, R. I., \& Adum-Attah, K. (2016). Music and dance for basic school teachers. Cape Coast, Ghana: Hampton Press.

Amuah, R., Adum-Attah, K., \& Arthur, K. K. (2011). Music and dance for colleges of education: Principles and practice. Cape Coast, Ghana: Kramad Publication Ltd.

Baiden, S. O., \& Amofa, D. (2008). Basic training and community practices for the teacher. Accra, Ghana: Ghana Ministry of Education, Science and Sports.

Ball, D. L., \& Forzani, F. M. (2009). The work of teaching and the challenges for teacher education." Journal of Teacher Education 60(5), 497-511.

Blake, B., \& Pope, T. (2008). Developmental psychology: Incorporating Piaget's and Vygotsky theories in classroom. Journal of Cross-Disciplinary Perspective Education 1 (1), 56-67.

Boafo-Agyemang, R. (2010). Creative arts in crisis: Teaching and learning of creative arts in selected schools in Kumasi. Accra, Ghana: Kwame Nkrumah University of Science and Technology.

Boamajeh, C. Y., \& Ohene-Okantah, M. (2000). An introduction to music education for music teachers in schools and colleges. Kumasi, Ghana: Payless Publication.

Branscome, E. E. (2014). Concert Programming and Performing as a Model for Lesson Planning and Teaching. Music Educators Journal 101(2). 71-74.

Button, S. (2010). Music teachers perceptions for effective teaching. Bulletin of the Council for Research in Music Education 183, 25-38.

Cohen, L., Manion, L., Morrison, K., \& Wyse, D. (2010). A guide to teaching practice (5th Ed). London, England: Routledge.

Đurđanović, M. M. (2015). The use of teaching aids and their importance for students' music education. International Journal of Cognitive Research in Science, Engineering and Education 3(2), 33-40.

Ekpo, E. O., \& Igiri, E. C. (2015). Impact of instructional materials in teaching and learning of biology in senior secondary schools. In Yakurr LG A. International Letters of Social and Humanistic Sciences 62, 27-33

Essa, E. L. (2003). Introduction to early childhood education (4th Ed). Clifton Park, NY: Delmar Learning.

Estrella, E. (2017). Classification of musical instruments: The Sachs-Honbostel system. Retrieved from https://www.thoughtco.com

Etikam, I., Musa, S. A., \& Alkassim, R. S. (2016). Comparison of convenience sampling and purposive sampling. American Journal of Theoretical and Applied Statistics 5 (1), 1-4.

Farrant, J. S. 1988. Principles and practice of education: Singapore: Longman.

Flolu, J., \& Amuah, R. (2003). An introduction to music education in Ghana for universities and colleges. Accra, Ghana: Black Mask Ltd.

Gurney, P. (2007). Five factors for effective teaching. New Zealand Journal of Teachers' Work 4(2), 89-98.

Harris, J., Mishra, P., \& Koehler, M. (2009). Teachers technological pedagogical content knowledge and learning activity types: Curriculum-based technology integration reframed. Journal of Research on Technology in Education 41(4), 393-416.

Hickok, R. (1993). Exploring music (5th Ed). Madison, WI: Brown and Benchmark. 
British Journal of Education

Vol.8, Issue 4, pp.70-81, April 2020

Published by ECRTD- UK

Print ISSN: ISSN 2054-6351

Online ISSN: ISSN 2054-636X

Irish National Teachers' Organisation. (2007). Approaches to teaching and learning. Retrieved from http://www.into.ie

Isbell, R. T., \& Raines, S. C. (2003). Creativity and the arts with young children. Clifton Park, NY: Delmar Learning.

Jay, J. K., \& Johnson, K. L. (2002). Capturing complexity: A typology of reflective practice for teacher education. Teaching and Teacher Education 18(1), 73-85.

Koomson, A. K. et al. (2003). Educational psychology. Cape Coast, Ghana: Centre for Continuing Education, University of Cape Coast.

McPherson, G. E., \& Renwick, J. M. (2011). Self-regulation and mastery of musical skills. Handbook of Self-Regulation of Learning and Performance. 234-248

Misigo, B. L., Kodero, H. M. N., \& Too, J. K. (2014). The qualities of effective secondary school teachers in Kenya. Journal of Emerging Trends in Educational Research and Policy Studies 5(8), 143-147.

Nacino-Brown, R., Oke, F. E., \& Brown, D. P. (1982). Curriculum and instruction: An introduction to methods of teaching. London, England: McMillan.

National Council for Curriculum and Assessment of Ghana. (2019). Creative arts syllabus for primary school. Accra, Ghana: Ministry of Education.

Nketia, J. H. K. (1988). The music of Africa. London, England: Victor Gollancz Ltd.

Owusu-Banahene, N. O. (2008). Educational psychology. Kumasi, Ghana: Nacro Printing Works.

Ramsden, P. (2003). Learning to teach in a higher education (2nd Ed). London, England: Routledge.

Reece, I., \& Walker, S. (1994). Teaching training and learning: A practical guide (2nd Ed). Sunderland, England: Business Education Publishing Ltd.

Robinson, E. T., \& Frances, K. K. (2000). Theory and practice: Discovery through reflection. Journal of Pharmacy Teaching 8 (2), 63-76.

Scott, S. J. (2011). Constructivist perspectives for developing and implementing lesson plans in general music. General Music Today 25(2), 24-30.

Sematwa, E. M. W. (2010). Piaget's theory of intellectual development and its implication for instructional management at pre-secondary school level. Educational Research and Reviews 5 (7), 366-371.

Tamakloe, E. K., Atta, E. T., \& Amedahe, F. K. (2005). Principles and methods of teaching. Accra, Ghana: Ghana Universities Press.

Tawiah, A. et al. (2016). National teachers' standards and teachers education curriculum framework for Ghana. Accra, Ghana: Ministry of Education.

Wenglinsky, H. (2000). How teaching matters: Bringing the classroom back into the discussions of teacher quality. Princeton, NJ: Educational Testing Service. 